\title{
Chemistry and Antidiabetic Effects of Phlogacanthus thyrsiflorus Nees Flowers
}

\author{
MD Ranzu Ahmed ${ }^{1,2}$, Tania Sultana ${ }^{3}$, Rayesha Routary ${ }^{4}$, MD Shahinul Haque Khan ${ }^{1}$, Khozirah Shaari ${ }^{5}$, M Abu Sayeed ${ }^{2}$, M Mosihuzzaman Mn $^{1,6}$ \\ and Begum Rokeya ${ }^{7 *}$
}

${ }^{1}$ Department of Chemistry, Bangladesh University of Health Sciences (BUHS), Dhaka, Bangladesh

${ }^{2}$ Department of Applied Chemistry and Chemical Engineering, University of Rajshahi, Rajshahi, Bangladesh

${ }^{3}$ Jahangirnagar University, Savar, Dhaka, Bangladesh

${ }^{4}$ Government Ayurvedic College and Hospital, Guwahati, Assam, India

${ }^{5}$ Laboratory of Natural Products, Institute of Bioscience, University Putra Malaysia, Selangor, Malaysia

${ }^{6}$ Department of Chemistry, University of Dhaka, Dhaka, Bangladesh

${ }^{7}$ Department of Pharmacology, Bangladesh University of Health Sciences (BUHS), Dhaka, Bangladesh

\begin{abstract}
The present study was carried out to evaluate the chemical constituents and antidiabetic activity of flower extracts of Phlogacanthus thyrsiflorus Nees in streptozotocin induced diabetic Long-Evans rats by feeding for 28 days. The ethanolic extract $(1.25 \mathrm{mg} / \mathrm{kg}$ bw) exhibited significant reduction of fasting serum glucose level in diabetic rats. The ethanolic extract also showed improvement in parameters of lipid profile. Five compounds namely, $\beta$ - sitosterol (1), stigmasterol (2), 8(17),13-labdadien-15,16-olide-19-oic acid (3), 19-hydroxy-8(17),13labdadien-15,16-olide (4) were isolated from the dichloromethane extract and 2-(3,4-dihydroxyphenyl)-5,7dihydroxy-4-chromenone (Luteolin) (5) were isolated from the 1-butanol part of methanol extract of flowers. The structures of these compounds were elucidated by extensive spectroscopic studies. This is the first report of isolation of compounds (1-5) from flowers of this plant. The activities of the flower extract may be due to the presence of some of these compounds which demands further studies.
\end{abstract}

Keywords: Phlogacanthus thyrsiflorus Nees; Streptozotocin; Type 2 diabetic model rats; Hypoglycemic effect; Isolation of compounds

\section{Introduction}

Medicinal plants from time immemorial have been used frequently for the treatment of diabetes [1,2]. Dependence on plant materials for managing diabetes mellitus is increasing due to its easy availability and low cost with often wrongly perceived reduced toxicity $[3,4]$. Therefore, with up surging interests in antidiabetic plant materials, there is an urgent need for thorough scientific investigations of many potential plants for both efficacy and potential toxicities. However, the challenge of determining specific active components with good pharmacological activities still remains [5].

Phlogacanthus thyrsiflorus Nees (Acanthaceae) locally known as rambasak is a large shrub found usually in the sub-tropical Himalayas, Bihar, North Bengal, Assam and Bangladesh [6]. The shrub grows during May to August. The leaves are elliptical. The flowers are yellow in colour. Flowers taste bitter when it is taken after frying. It grows in forest and regenerated from seeds [7] and flowering occurs in the month of February to April [8]. Different parts of this plant are being used for the cure of different ailments like, fever, gastritis, pharyngitis, cough, bronchial asthma, rheumatism and many more [9]. This botanical herbaceous plant is widely used as verdant foods, medicine practice and traditional medicines. The aqueous extract of the flower of $P$. thyrsiflorus have been claimed to possess significant reduction of blood glucose level $(\mathrm{p}<0.0001)$, serum cholesterol $(P<0.01)$ and increase in liver glycogen $(P<0.0001)$ on steptozotocin induced diabetic mice [10]. The leaves are reported to contain diterpene lactone, phlogantholide, saponins and flavonoids and their glycosides [9]. The objective of this work was to investigate the scientific basis for its use in the treatment of diabetes mellitus. Therefore, the study was designed to evaluate the antidiabetic effect of $P$. thyrsiflorus flowers on type 2 diabetic model rats and isolate compounds from it.

\section{Experimental}

\section{General}

${ }^{1} \mathrm{H}$ and ${ }^{13} \mathrm{C}-\mathrm{NMR}$ spectra including DEPT, $1 \mathrm{H}-1 \mathrm{H}$ COSY and HMBC spectra were recorded on BRUKER DBX-400 MHz NMR and VARIAN $500 \mathrm{MHz}$ NMR spectrometers. The chemical shifts are reported in ppm with respect to residual non-deuterated solvent signals. The mass spectra were recorded at $70 \mathrm{ev}$ with Finnigan 4021 and GCMS- QP2010 Ultra instrument. The fast atom bombardment mass spectrum $\left(\mathrm{FAB}^{+} \mathrm{MS}\right)$ was recorded as a positive ion mode with $\mathrm{m} / \mathrm{z}$ ranging between $0.0020-1000.0000$.

\section{Plant material}

Flowers of Phlogacanthus thyrsiflorus Nees were collected from Dibrughar, Assam, India. The flower was identified by Taxonomist of Bangladesh National Herbarium (Accession number 42992). The collected materials were cleaned, air dried and finally dried in an oven at $40^{\circ} \mathrm{C}$. The dried flowers were ground to a course powder with a cyclotec grinder.

\section{Extraction}

The powdered flowers (300 g) of Phlogacanthus thyrsiflorus Nees were successively extracted at room temperature with dichloromethane

*Corresponding author: Begum Rokeya, Department of Pharmacology, Bangladesh University of Health Sciences (BUHS), 125/1 Darus Salam, Mirpur-1, Dhaka-1216, Bangladesh, Tel: +8801711811350; E-mail: b_rokeya@yahoo.com

Received June 16, 2016; Accepted June 28, 2016; Published July 02, 2016

Citation: Ahmed R, Sultana T, Routary R, Khan SH, Shaari K, et al. (2016) Chemistry and Antidiabetic Effects of Phlogocanthus thyrsiflorus Nees Flowers. Nat Prod Chem Res 4: 229. doi:10.4172/2329-6836.1000229

Copyright: ( 2016 Ahmed R, et al. This is an open-access article distributed under the terms of the Creative Commons Attribution License, which permits unrestricted use, distribution, and reproduction in any medium, provided the original author and source are credited. 
(DCM) $(2 \mathrm{~L} \times 4: 24 \mathrm{hrs})$ followed by ethyl acetate $(2 \mathrm{~L} \times 4: 24 \mathrm{hrs})$ and methanol $(2 \mathrm{~L} \times 4: 24 \mathrm{hrs})$. The extracts were filtered off and the filtrates were evaporated to dryness at $40^{\circ} \mathrm{C}$ with rotary vacuum evaporator and finally freeze dried to afford $8.1 \mathrm{~g}$ of DCM, $3.0 \mathrm{~g}$ of ethyl acetate and $16 \mathrm{~g}$ of methanol extracts. The powdered flowers $(800 \mathrm{~g})$ were also successively extracted with aq $80 \%$ ethanol $(2 \mathrm{~L} \times 6$ times) to give $14 \mathrm{~g}$ of aq $80 \%$ ethanol extract. The residue (142 $\mathrm{g}$ ) was suspended in water $(3 \mathrm{~L})$ and partitioned with DCM $(3 \mathrm{~L} \times 3$ times) followed by 1-butanol ( $3 \mathrm{~L} \times 3$ times). The DCM and 1-butanol soluble parts were evaporated to dryness to get DCM (36.59 g) and 1-butanol $(54.0 \mathrm{~g})$ soluble extractives.

\section{Isolation of compounds}

The first dichloromethane extract $(8.1 \mathrm{~g})$ was fractionated by column chromatography (silica gel) using gradient elution of $n$-hexane, ethyl acetate and methanol with $10 \%$ increment and fourteen fractions $\left(1 \mathrm{~F}_{1}-1 \mathrm{~F}_{14}\right)$ were collected. Fraction $1 \mathrm{~F}_{5}$ was again fractionated over a silica gel column and eluted gradually with n-hexane and the polarity was increased by adding ethyl acetate and methanol in different proportion and six fractions $\left(2 \mathrm{~F}_{1}-2 \mathrm{~F}_{6}\right)$ were collected. Compound $\mathbf{1}$ was purified as needle shaped crystal from fraction $2 \mathrm{~F}_{5}$ by washing the crystal with $\mathrm{n}$-hexane and methanol. Fraction $2 \mathrm{~F}_{6}$ was purified to give compound 2 over a silica gel column and eluted with the same mobile phase. Compound 2, ( $\mathrm{R}_{\mathrm{f}}$ value of 0.54$)$ was isolated as white needles, after washing the crystal with dichloromethane and methanol.

Fraction $1 \mathrm{~F}_{11}$ showed brownish crystals. Then the fraction was again fractionated over a silica gel column and eluted gradually with $\mathrm{n}$-hexane and the polarity was increased by adding ethyl acetate and methanol in different proportion and fourteen fractions $\left(3 \mathrm{~F}_{1}-3 \mathrm{~F}_{14}\right)$ were collected. Fraction $3 \mathrm{~F}_{5}$ showed crystal and was purified to Compound 3 by washing the crystal with the same solvent $n$-hexane and methanol. Fraction $3 \mathrm{~F}_{8}$ also showed crystal. Compound 4 was isolated by washing the crystal with the same washing solvents.

The butanol extract (52.0 g) was chromatographed over Sephadex LH-20 column and eluted gradually with deionized water and methanol mixtures with decreasing polarity and fractions $\left(4 \mathrm{~F}_{1}-4 \mathrm{~F}_{71}\right)$ were collected. Fraction $4 \mathrm{~F}_{35}$ was purified to compound $5(19.0 \mathrm{mg})$ by HPLC [Column RP-18 ( $250 \mathrm{~mm} \times 4.6 \mathrm{~mm}$ i.d.), mobile phase $60 \%$ aqueous acetonitrile, flow rate: $1.0 \mathrm{~mL} / \mathrm{min}$, $\mathrm{UV}$ detection at $254 \mathrm{~nm}$ and column oven temperature $\left.37^{\circ} \mathrm{C}\right]$. The isolated compounds had the following characteristics:

Compound 1 was needle shaped crystals with m.p. $137-38^{\circ} \mathrm{C}$. The ${ }^{1} \mathrm{H}$ - and ${ }^{13} \mathrm{C}-\mathrm{NMR}$ spectral data $\left(\mathrm{CDCl}_{3}\right)$ are presented in Tables 1 and 2 , respectively.

Compound 2 was needle shaped crystals with m.p. $162.5^{\circ} \mathrm{C}$. The crystal of the compound was soluble in $\mathrm{CHCl}_{3}$. From the ${ }^{1} \mathrm{H}$ - and ${ }^{13} \mathrm{C}$-NMR spectral data $\left(\mathrm{CDCl}_{3}\right)$ are presented in Tables 1 and 2, respectively.

Compound 3 was long fatty shaped crystals. It gave single spot on TLC with $\mathrm{R}_{\mathrm{f}}$ value 0.53 (n-hexane : ethyl acetate; 3:7). The ${ }^{1} \mathrm{H}$ and ${ }^{13} \mathrm{C}$-NMR spectral data $\left(\mathrm{CDCl}_{3}\right)$ are presented in Tables 1 and 2, respectively. GCMS m/z $332\left[\mathrm{M}+\mathrm{H}^{+}\right]$. FTIR $(\mathrm{KBr}) v_{\max }: 2940,1691$, $1528,669 \mathrm{~cm}^{-1}$.

Compound 4 was white powder. It gave single spot on TLC with $R_{f}$ value 0.50 (n-hexane : ethyl acetate; $4: 6$ ). The ${ }^{1} \mathrm{H}$ - and ${ }^{13} \mathrm{C}$-NMR spectral data $\left(\mathrm{CDCl}_{3}\right)$ are presented in Tables 1 and 2, respectively. GCMS m/z $334\left[\mathrm{M}+\mathrm{H}^{+}\right]$. FTIR $(\mathrm{KBr}) v_{\max }: 2935,1714,1528,670 \mathrm{~cm}^{-1}$.

Compound 5 was brownish powder. The molecular mass of this compound was found to be $286 \mathrm{~g} / \mathrm{mol}$. From the ${ }^{1} \mathrm{H}$ - and ${ }^{13} \mathrm{C}-\mathrm{NMR}$ spectral data $\left(\mathrm{CDCl}_{3}\right)$ are presented in Tables 1 and 2, respectively.

\section{Experimental animals}

The study was conducted on adult Long-Evans rats of both sexes (weighing 180-220 g). They were bred at the BIRDEM animal house and maintained at a constant room temperature of $22^{\circ} \mathrm{C}, 40-70 \%$ humidity conditions and the natural day-night cycle with an ad libitum access to food and water except the day of experimental procedure when animals were used after $12 \mathrm{hrs}$ fasting. The rats had no access to food during the whole period of blood sampling. The influence of circadian rhythms was avoided by starting all the experiments at 8.30 a.m. Experiments on the animals were performed following the guidelines approved by Bangladesh Association for Laboratory Animal Science.

\section{Induction of Type 2 diabetes to the rats}

Type 2 diabetes was induced by a single intraperitoneal injection of streptozotocin (STZ, Upjohn Company, Kalamazoo, MI, USA) at a dose of $90 \mathrm{mg} / \mathrm{kg}$ body weight to $48 \mathrm{hrs}$ old pups.

Three months later of STZ injection an oral glucose $(2.5 \mathrm{~g} / \mathrm{kg} \mathrm{bw})$ tolerance test was performed and type 2 diabetic model rats (blood glucose level 7-9 $\mathrm{mmol} / \mathrm{L}$ at fasting condition) were selected to carry out the experiment with ethanolic extract of $P$ thyrsiflorus flowers. The length of experiment was 28 days. A total of 18 Type 2 rats were used in this experiment. The rats were divided into the following three groups of six rats in each group:

1) Type 2 control group (fed with water)

2) Type 2 positive control group (fed with glibenclamide at a dose of $5 \mathrm{mg} / \mathrm{kg} \mathrm{bw}$ )

3) Type 2 treated group (fed with $80 \%$ ethanol extract of $P$. thyrsiflorus at a dose of $1.25 \mathrm{gm} / \mathrm{kg} \mathrm{bw} / 10 \mathrm{~mL}$ of water).

The rats were fed consecutively for 28 days with a single feeding every day. The body weight of each rat was measured on day $0,7,14,21$ and 28 day of experimental period.

\section{Collection of blood samples for biochemical procedures}

The rats were kept fasting for $12 \mathrm{hrs}$ on the 0 day and blood was collected from the fasted rats by amputation of the tail tip under (diethyl ether) anesthesia. On the $29^{\text {th }}$ day after $12 \mathrm{hrs}$ fasting blood was collected from the rats by cardiac puncture. The collected blood samples were centrifuged; the serum was separated and kept frozen at $-20^{\circ} \mathrm{C}$ until analysis of different biochemical parameters.

\section{Biochemical analysis}

The parameters measured were: serum glucose (glucose-oxidase), serum insulin (ELISA) and serum lipids by enzymatic-colorimetric method.

\section{Statistical analysis}

Data from the experiments were analyzed using the Statistical Package for Social Science (SPSS) software for windows version 12 (SPSS Inc., Chicago, Illinois, USA). All the data were expressed as Mean \pm SD as appropriate. Statistical analyses of the results were performed by using the student's t-test or ANOVA (analysis of variance) followed by Bonferroni post hoc test. The limit of significance was set at $\mathrm{p}<0.05$. In addition, the percentage changes compared to the initial value of the corresponding groups of rats were calculated to help the understanding of the effect of $P$. thyrsiflorus flowers on different parameters studied. 
Citation: Ahmed R, Sultana T, Routary R, Khan SH, Shaari K, et al. (2016) Chemistry and Antidiabetic Effects of Phlogocanthus thyrsiflorus Nees Flowers. Nat Prod Chem Res 4: 229. doi:10.4172/2329-6836.1000229

Page 3 of 7

\begin{tabular}{|c|c|c|c|c|c|}
\hline \multirow{2}{*}{ Position } & \multicolumn{5}{|c|}{$\delta_{\mathrm{H}}$, Multi $(J$ in Hz) } \\
\hline & 1 & 2 & 3 & 4 & 5 \\
\hline 1 & - & - & $1.78(\mathrm{~m})$ & $1.78(\mathrm{~m})$ & - \\
\hline 2 & - & - & $1.63(\mathrm{~m})$ & $1.65(\mathrm{~m})$ & - \\
\hline 3 & $3.52(1 \mathrm{H}, \mathrm{m})$ & $3.52(1 \mathrm{H}, \mathrm{m})$ & $1.67(\mathrm{~m})$ & $1.69(\mathrm{~m})$ & $(6.53, \mathrm{~s})$ \\
\hline 4 & - & - & - & - & - \\
\hline 5 & - & - & $1.97(\mathrm{~d} ; \mathrm{J}=11.65 \mathrm{~Hz})$ & $1.96(\mathrm{~d} ; \mathrm{J}=11.65 \mathrm{~Hz})$ & - \\
\hline 6 & $5.35(1 \mathrm{H}, \mathrm{brs})$ & $5.35(1 \mathrm{H}, \mathrm{brs})$ & $\begin{array}{c}1.53(\mathrm{dddd} / \mathrm{dq}, \mathrm{J}=4.15,12.90 \\
25.65 \mathrm{~Hz}) \\
1.41(\mathrm{~d} ; \mathrm{J}=10.75 \mathrm{~Hz})\end{array}$ & $\begin{array}{c}1.53(\mathrm{dddd} / \mathrm{dq}, \mathrm{J}=4.15,12.90 \\
25.65 \mathrm{~Hz}) \\
1.40(\mathrm{~d} ? ; \mathrm{J}=10.75 \mathrm{~Hz})\end{array}$ & $(6.43, \mathrm{br} s)$ \\
\hline 7 & - & - & $\begin{array}{c}2.40(\mathrm{~d} ; \mathrm{J}=12.75 \mathrm{~Hz}) \\
2.08(\mathrm{ddd} / \mathrm{dt} ; \mathrm{J}=4.12,12.35,16.80 \\
24.7 \mathrm{~Hz})\end{array}$ & $\begin{array}{c}2.40(\mathrm{~d} ; \mathrm{J}=12.75 \mathrm{~Hz}) \\
2.24(\mathrm{ddd} / \mathrm{dt} ; \mathrm{J}=4.12,12.35 \\
16.80,24.7 \mathrm{~Hz})\end{array}$ & - \\
\hline 8 & - & - & - & - & (6.2. br s) \\
\hline 9 & - & - & 1.73 & 1.73 & - \\
\hline 10 & - & - & - & - & - \\
\hline 11 & - & - & $\begin{array}{l}1.82(\mathrm{~m}) \\
1.67(\mathrm{~m})\end{array}$ & $\begin{array}{l}1.82(\mathrm{~m}) \\
1.66(\mathrm{~m})\end{array}$ & - \\
\hline 12 & - & - & $\begin{array}{c}2.29(\mathrm{~m}) \\
2.59(\mathrm{sept} / \mathrm{m} ; \mathrm{J}=3.35,5.80,8.65 \\
14,45 \mathrm{~Hz})\end{array}$ & $\begin{array}{c}2.29(\mathrm{~m}) \\
2.57(\text { sept } / \mathrm{m} ; \mathrm{J}=3.35,5.80 \\
8.65, \quad 14,45 \mathrm{~Hz})\end{array}$ & - \\
\hline 13 & - & - & - & - & - \\
\hline 14 & - & - & $5.86(s)$ & $5.85(\mathrm{~s})$ & $(6.89, \mathrm{~d}, \mathrm{~J}-12 \mathrm{~Hz})$ \\
\hline 15 & - & - & - & - & $(7.38, \mathrm{~d}, \mathrm{~J}-12 \mathrm{~Hz})$ \\
\hline 16 & - & - & $\begin{array}{l}4.72(\mathrm{~s}) \\
4.70(\mathrm{~s})\end{array}$ & $\begin{array}{l}4.73(\mathrm{~s}) \\
4.71(\mathrm{~s})\end{array}$ & \\
\hline 17 & - & - & $\begin{array}{l}4.90(\mathrm{~s}) \\
4.49(\mathrm{~s})\end{array}$ & $\begin{array}{l}4.88(\mathrm{~s}) \\
4.77(\mathrm{~s})\end{array}$ & \\
\hline 18 & $0.68(3 \mathrm{H}, \mathrm{s})$ & $0.70(3 \mathrm{H}, \mathrm{s})$ & $1.16(\mathrm{~s})$ & $1.1(\mathrm{~s})$ & \\
\hline 19 & $1.01(3 \mathrm{H}, \mathrm{s})$ & $1.01(3 \mathrm{H}, \mathrm{s})$ & - & - & \\
\hline 20 & - & - & $0.74(s)$ & $0.69(\mathrm{~s})$ & \\
\hline 21 & $0.92(3 \mathrm{H}, \mathrm{d}, 6.4)$ & $1.02(3 \mathrm{H}, \mathrm{d}, 7.5)$ & & & \\
\hline 22 & - & $5.14(\mathrm{dd}, 8.4,8.8)$ & & & \\
\hline 23 & - & $5.02(\mathrm{dd}, 8.4,8.4)$ & & & \\
\hline 24 & - & - & & & \\
\hline 25 & - & - & & & \\
\hline 26 & $0.81(3 \mathrm{H}, \mathrm{d}, 6.5)$ & $0.79(3 \mathrm{H}, \mathrm{d} .6 .5)$ & & & \\
\hline 27 & $0.83(3 \mathrm{H}, \mathrm{d}, 6.5)$ & $0.85(3 \mathrm{H}, \mathrm{d}, 6.5)$ & & & \\
\hline 28 & - & - & & & \\
\hline 29 & $0.85(3 \mathrm{H}, \mathrm{t}, 7.5)$ & $0.80(3 \mathrm{H}, \mathrm{t}, 7.5)$ & & & \\
\hline
\end{tabular}

Table 1: ${ }^{1} \mathrm{H}-\mathrm{NMR}$ spectral data for Compounds (1-5).

\begin{tabular}{|c|c|c|c|c|c|}
\hline \multirow{2}{*}{ Position } & \multicolumn{5}{|c|}{$\delta_{c}$, Multi } \\
\hline & 1 & 2 & 3 & 4 & 5 \\
\hline 1 & $37.3 t$ & $37.3 \mathrm{t}$ & $38.0 \mathrm{t}$ & $39.2 \mathrm{t}$ & \\
\hline 2 & $31.7 t$ & $31.5 \mathrm{t}$ & $18.3 \mathrm{t}$ & $21.5 \mathrm{t}$ & 123.8 \\
\hline 3 & $71.8 \mathrm{~d}$ & $71.8 \mathrm{~d}$ & $37.0 \mathrm{t}$ & $35.4 \mathrm{t}$ & 103.8 \\
\hline 4 & $42.3 \mathrm{t}$ & $42.3 \mathrm{t}$ & $47.4 \mathrm{~s}$ & $56.3 \mathrm{~s}$ & 183.9 \\
\hline 5 & $140.8 \mathrm{~s}$ & $140.8 \mathrm{~s}$ & $49.4 d$ & $56.4 \mathrm{~s}$ & 166.7 \\
\hline 6 & $121.7 \mathrm{~d}$ & $121.7 \mathrm{~d}$ & $26.8 \mathrm{t}$ & $27.2 \mathrm{t}$ & 100.3 \\
\hline 7 & $31.9 \mathrm{t}$ & $31.9 \mathrm{t}$ & $37.7 \mathrm{t}$ & $38.6 \mathrm{t}$ & 166.4 \\
\hline 8 & $31.9 \mathrm{~d}$ & $31.7 \mathrm{~d}$ & $147.1 d$ & $115.3 \mathrm{~s}$ & 95.1 \\
\hline 9 & $51.2 \mathrm{~d}$ & $51.3 d$ & $56.2 \mathrm{~d}$ & $65.1 \mathrm{~s}$ & 159.4 \\
\hline 10 & $36.5 \mathrm{~s}$ & $36.5 \mathrm{~s}$ & $39.0 \mathrm{~s}$ & $39.7 \mathrm{~s}$ & 105.2 \\
\hline 11 & $21.1 \mathrm{t}$ & $21.1 \mathrm{t}$ & $21.2 \mathrm{t}$ & $24.5 \mathrm{~s}$ & 114.1 \\
\hline 12 & $39.8 \mathrm{t}$ & $39.7 \mathrm{t}$ & $27.5 \mathrm{t}$ & $27.5 \mathrm{t}$ & 147.0 \\
\hline 13 & $42.2 \mathrm{~s}$ & $42.2 \mathrm{~s}$ & $170.9 \mathrm{~s}$ & $147.5 \mathrm{~s}$ & 151.0 \\
\hline 14 & $56.8 \mathrm{~d}$ & $56.8 d$ & $115.2 \mathrm{~s}$ & $115.3 \mathrm{t}$ & 116.8 \\
\hline 15 & $24.3 \mathrm{t}$ & $24.3 \mathrm{t}$ & $174.2 \mathrm{~s}$ & $171.0 \mathrm{~s}$ & 120.4 \\
\hline
\end{tabular}




\begin{tabular}{|l|l|l|l|l|}
\hline 16 & $28.2 \mathrm{t}$ & $28.2 \mathrm{t}$ & $73.1 \mathrm{t}$ & $73.2 \mathrm{~d}$ \\
\hline 17 & $56.1 \mathrm{~d}$ & $56.1 \mathrm{~d}$ & $107.2 \mathrm{t}$ & $106.8 \mathrm{t}$ \\
\hline 18 & $12.0 \mathrm{q}$ & $11.8 \mathrm{q}$ & $16.3 \mathrm{q}$ & $19.0 \mathrm{~s}$ \\
\hline 19 & $19.4 \mathrm{q}$ & $19.8 \mathrm{q}$ & $14.2 \mathrm{q}$ \\
\hline 20 & $36.1 \mathrm{~d}$ & $40.5 \mathrm{~d}$ & $15.3 \mathrm{~d}$ \\
\hline 21 & $18.8 \mathrm{q}$ & $21.2 \mathrm{q}$ & \\
\hline 22 & $34.0 \mathrm{t}$ & $138.3 \mathrm{~d}$ & \\
\hline 24 & $26.1 \mathrm{t}$ & $129.3 \mathrm{~d}$ & \\
\hline 25 & $45.9 \mathrm{~d}$ & $50.2 \mathrm{~d}$ & \\
\hline 26 & $29.2 \mathrm{~d}$ & $31.7 \mathrm{~d}$ & \\
\hline 27 & $19.0 \mathrm{q}$ & $21.1 \mathrm{q}$ & \\
\hline 28 & $19.0 \mathrm{q}$ & $19.0 \mathrm{q}$ & \\
\hline 29 & $29.1 \mathrm{t}$ & $25.4 \mathrm{t}$ & \\
\hline
\end{tabular}

Table 2: ${ }^{13} \mathrm{C}-\mathrm{NMR}$ spectral data of Compounds (1-5).

\begin{tabular}{|c|c|c|c|}
\hline Group & $\begin{array}{c}\text { Glucose }(\mathrm{mmol} / \mathrm{L}) \\
0 \text { day }\end{array}$ & $\begin{array}{c}\text { Glucose }(\mathrm{mmol} / \mathrm{L}) \\
14 \text { day }\end{array}$ & $\begin{array}{c}\text { Glucose }(\mathrm{mmol} / \mathrm{L}) \\
28 \text { day }\end{array}$ \\
\hline $\begin{array}{c}\text { T2WC } \\
(\mathrm{n}=6)\end{array}$ & $\begin{array}{c}7.57 \pm 0.52 \\
(100 \%)\end{array}$ & $\begin{array}{c}8.30 \pm 0.88 \\
(110 \%)\end{array}$ & $\begin{array}{c}8.52 \pm 1.43 \\
(113 \%)\end{array}$ \\
\hline $\begin{array}{l}\text { Gliben } \\
(n=6)\end{array}$ & $\begin{array}{c}7.99 \pm 1.03 \\
(100 \%)\end{array}$ & $\begin{array}{c}6.59 \pm 1.30 \\
(82 \%)\end{array}$ & $\begin{array}{c}6.39 \pm 1.14^{*} \\
(80 \%)\end{array}$ \\
\hline $\begin{array}{l}\text { Ethanol ext } \\
\qquad(n=6)\end{array}$ & $\begin{array}{c}8.86 \pm 0.79 \\
(100 \%)\end{array}$ & $\begin{array}{c}7.17 \pm 1.22 \\
(81 \%)\end{array}$ & $\begin{array}{c}6.42 \pm 1.32^{*} \\
(72 \%)\end{array}$ \\
\hline
\end{tabular}

Results are expressed as Mean $\pm \mathrm{SD}$; " $\mathrm{p}<0.05$ vs Type 2 water control (ANOVA with post Hoc Bonferroni test). T2WC=Type 2 Water Control, Gliben=Glibenclamide. Table 3: Effect of $P$. thyrsiflorus flower extract on fasting blood glucose level of STZ-induced Type 2 diabetic model rats.

\section{Results and Discussion}

\section{Chemistry of $P$. thyrsiflorus}

Repeated chromatographic separation and purification of dichloromethane and 1-butanol part of methanol extracts of flowers of $P$. thyrsiflorus provided five compounds (1-5). The ${ }^{13} \mathrm{C}-\mathrm{NMR}$ (Table 2) of 1 showed 29 carbons including an oxymethine carbon signal at $\delta_{C} 71.8$ and two olefinic carbons at $\delta_{C} 140.8$ and $\delta_{C} 121.7$ characteristic of spirostene [11]. The multiplicities of the carbon signals were determined by DEPT 135 experiments which revealed the presence of 6 methyls, 11 methylenes, 9 methines and 3 quaternary carbon atoms in compound 1 . The ${ }^{1} \mathrm{H}$ - (Table 1 ) and ${ }^{13} \mathrm{C}$ - (Table 2) NMR spectral data of compound $\mathbf{1}$ are similar to the reported data for $\beta$-sitosterol $[12,13]$. Therefore, the structure of compound $\mathbf{1}$ is characterized as $\beta$-sitosterol (Figure 1). $\beta$-Sitosterol is a very common steroidal compound present in almost all kinds of plants. $\beta$-Sitosterol is reported for the first time from the flowers of this plant.

The ${ }^{1} \mathrm{H}$-NMR spectral data (Table 1 ) of compound 2 revealed multiplet signal for an oxymethine proton at $\delta_{\mathrm{H}} 3.52$. The olefin proton resonating at $\delta_{\mathrm{H}} 5.35$ was charecterististic of 5 -steroids [11]. The spectrum revealed signals at $\delta_{\mathrm{H}} 0.68$ and 1.01 (3H each) assignable to two tertiary methyl groups at C-18 and C-19, respectively. The signals of two further secondary methyl groups at $\delta_{\mathrm{H}} 0.84(J=7.3 \mathrm{~Hz})$ and $\delta_{\mathrm{H}} 0.83(J=7.3 \mathrm{~Hz})$ could be attributed to two methyl groups at C-26 and C-27, respectively. The doublet at $\delta_{\mathrm{H}} 0.92(\mathrm{~d}, J=8.0 \mathrm{~Hz}, \mathrm{H}-21)$ was demonstrative of a methyl group at C-21. On the other hand, the threeproton triplet at $\delta_{\mathrm{H}} 0.81$ could be assigned to the primary methyl group at C-29. The ${ }^{1} \mathrm{H}$ - (Table 1 ), ${ }^{13} \mathrm{C}$ - (Table 2) and DEPT-NMR spectra of compound 2 are similar to the reported data of stigmasterol $[12,13]$. Therefore, the structure of compound $\mathbf{2}$ is characterized as stigmasterol. Stigmasterol is very common steroidal compound present in many plants but stigmasterol is the first report from the flowers of this plant.

Compound 3 is a diterpenoid compound. Its IR (KBr) v: 2940
(-OH), $1691(>\mathrm{C}=\mathrm{O}), 1528, \mathrm{~cm}^{-1}$ spectrum indicated the presence of hydroxyl and carbonyl groups, and carbon carbon double bonds in the compound 3. The molecular formula $\mathrm{C}_{20} \mathrm{H}_{28} \mathrm{O}_{4}$ of $\mathbf{3}$ was deduced from GCMS data. Three $\mathrm{CH}_{2}$ proton appears at $\delta_{\mathrm{C}} 1.63(\mathrm{~m}), 1.67(\mathrm{~m}), 1.78$ (m). Two $\mathrm{H}$ appears at $\delta_{\mathrm{H}} 4.70(\mathrm{~s})$ and $4.72(\mathrm{~s})$ for the $\mathrm{CH}_{2}$ of furan ring. Two olefinic $\mathrm{H}$ of 17 carbon appears at $\delta_{\mathrm{H}} 4.90$ (s) and 4.49 (s). Another olefinic $\mathrm{H}$ of furan ring comes at $\delta_{\mathrm{H}} 5.86$ (s). Carboxylic functional group containing carbon appears at $\delta_{C} 184.8$, furan ring containing quarternary carbon at $\delta_{\mathrm{C}} 170.9$ and cyclic carbonyl carbon at $\delta_{\mathrm{C}}$ 174.2. The ${ }^{1} \mathrm{H}-,{ }^{13} \mathrm{C}$ - and DEPT-NMR spectra of compound 3 are similar to the reported data of 8(17),13-labdadien-15,16-olide-19-oic acid $[9,14]$. Therefore, the structure of compound 3 is characterized as 8(17),13-labdadien-15,16-olide-19-oic acid. This is the first report of isolation of 8(17),13-labdadien-15,16-olide-19-oic acid from the flowers of this plant.

The molecular formula $\mathrm{C}_{20} \mathrm{H}_{30} \mathrm{O}_{4}$ of compound 4 was deduced from GCMS data. Compound $\mathbf{4}$ has three $\mathrm{CH}_{2}$ protons appearing at $\delta_{\mathrm{H}} 1.65(\mathrm{~m}), 1.69(\mathrm{~m})$ and $1.78(\mathrm{~m})$. Two $\mathrm{H}$ appears at $\delta_{\mathrm{H}} 4.71(\mathrm{~s})$ and 4.73 (s) for the $\mathrm{CH}_{2}$ of furan ring. Two olefinic $\mathrm{H}$ of 17 carbon appears at $\delta_{\mathrm{H}} 4.88$ (s) and 4.77 (s). Another olefinic $\mathrm{H}$ of furan ring comes at $\delta_{\mathrm{H}} 5.85$ (s). Hydroxyl functional group containing carbon appears at $\delta_{\mathrm{C}} 174.2$, furan ring containing quarternary carbon at $\delta_{\mathrm{C}} 147.5$ and cyclic carbonyl carbon at $\delta_{C} 171.0$. The ${ }^{1} \mathrm{H}$ - (Table 1 ), ${ }^{13} \mathrm{C}$ - (Table 2) and DEPT-NMR spectra of compound $\mathbf{4}$ are similar to the reported data of 8(17),13-labdadien-15,16-olide-19-oic acid [9,15] except the carboxylic acid functional group reduced to hydroxyl group. Therefore, the structure of compound 4 is characterized as 19-hydroxy-8(17),13labdadien-15,16-olide. This is first report of 19-hydroxy-8(17),13labdadien-15,16-olide from the flowers of this plant.

The molecular formula $\mathrm{C}_{15} \mathrm{H}_{10} \mathrm{O}_{6}$ was determined from $1 \mathrm{D}$ and 2D NMR data of compound 5 . The ${ }^{13} \mathrm{C}-\mathrm{NMR}$ spectrum of 5 displayed 15 carbon atoms, which is characteristic of a flavonoid type skeleton. The molecular mass of this compound is $286 \mathrm{~g} / \mathrm{mol}$. The ${ }^{1} \mathrm{H}$ - (Table 1), ${ }^{13} \mathrm{C}$ - (Table 2) and DEPT-NMR data of compound $\mathbf{5}$ are similar to 
<smiles>CC[C@H](CC[C@H](C)[C@H]1CCC2C3CC=C4C[C@@H](O)CC[C@]4(C)C3CC[C@]21C)C(C)C</smiles>

1<smiles>CC[C@H](/C=C/[C@@H](C)[C@H]1CCC2C3CC=C4C[C@@H](O)CC[C@]4(C)C3CC[C@]21C)C(C)C</smiles>

2<smiles>C[C@@H]1/C(=C\CC2=CC(=O)OC2)CC[C@]2(C)[C@](C)(C(=O)O)CCC[C@]12C</smiles>

3

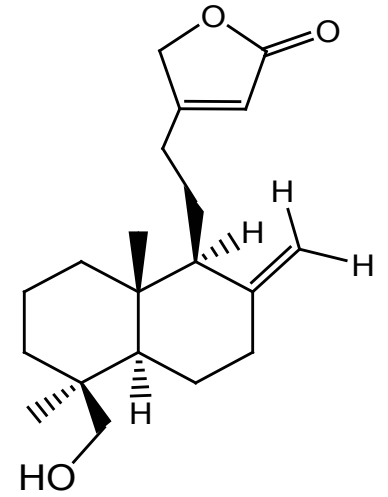

4<smiles>O=c1cc(-c2ccc(O)c(O)c2)oc2cc(O)cc(O)c12</smiles>

5

Figure 1: Structure of isolated 05 compounds from $P$. thyrsiflorus.

the reported data of luteolin [16,17]. On the basis of all the spectral data, the compound $\mathbf{5}$ is characterized as luteolin. Luteolin is a known compound and its IUPAC name is 2-(3,4-dihydroxyphenyl)5,7-dihydroxy-4-chromenone. Compound $\mathbf{5}$ is isolated for the first time from this plant.

\section{Antidiabetic effects of $P$. thyrsiflorus flowers}

Effect of $P$. thyrsiflorus on fasting serum glucose level of Type 2 diabetic model rats: Fasting serum glucose (FSG) levels of type 2 diabetic models rats of the three experimental groups were almost similar on 0 day (Table 3). After oral administration of respective treatment to the type 2 diabetic model rats of different groups for 28 days of experimental period, it was found that the FSG level of type 2 rats treated with ethanol extract of $P$. thyrsiflorus flowers showed a significant decrease compared to that of control group $(\mathrm{p}=0.042)$. Morever, It is seen from the Table 3 that ethanol extract treated group showed a $28 \%$ reduction of FSG level compared to 0 day value. Chakravaty et. al. found anti-hyperglycemic activity with $P$. thyrsiflorus flower on STZ induced diabetic mice [10]. As expected, glibenclamide also ameliorated the diabetic condition on $28^{\text {th }}$ day. Glibenclamide significantly $(\mathrm{p}=0.037)$ reduced fasting glucose on $28^{\text {th }}$ day when compared to that of control group. On the contrary, there was a $13 \%$ increase in the fasting glucose level of type 2 control group on $28^{\text {th }}$ day of experimental period compared to the baseline.
Effect of $P$. thyrsiflorus flower on serum insulin level of STZinduced Type 2 diabetic model rats: The effect of $P$. thyrsiflorus flowers extract on insulinemic status of type 2 diabetic model rats was observed (Figure 2). At the beginning of the study period, all groups showed almost similar serum insulin level. After 28 days consecutive feeding glibenclamide treated rats showed more than fivefold increase in serum insulin level which was highly significant $(p<0.001)$. Ethanol extract showed a $23 \%$ increase in serum insulin level at the end of the study period compared to baseline level, however the increase was not significant. As it is seen from the table, T2WC group showed a $48 \%$ reduction compared to baseline value which is logical. Type 2 diabetic rat model those are produced in this study by injecting STZ to neonate rats have hypoinsulinemia which resemble beta cell secretory defect. Therefore, in this study the condition of the Type 2 water control group deteriorates with time which is manifested by hyperglycemia and decreased serum insulin level.

Effect of $P$. thyrsiflorus flowers extract on the body weight of Type 2 diabetic model rats: The effect of $P$. thyrsiflorus flowers extract on body weight of type 2 diabetic model rats was observed during 28 days study period. Body weight of each rat was taken at seven days interval. No significant change was found in body weight in any group after 28 days of study (Table 4).

Effects of $\boldsymbol{P}$. thyrsiflorus flowers extract on serum cholesterol and triglyceride levels of Type 2 diabetic model rats: Effect of $P$. thyrsiflorus flowers extract on serum cholesterol and triglyceride level 


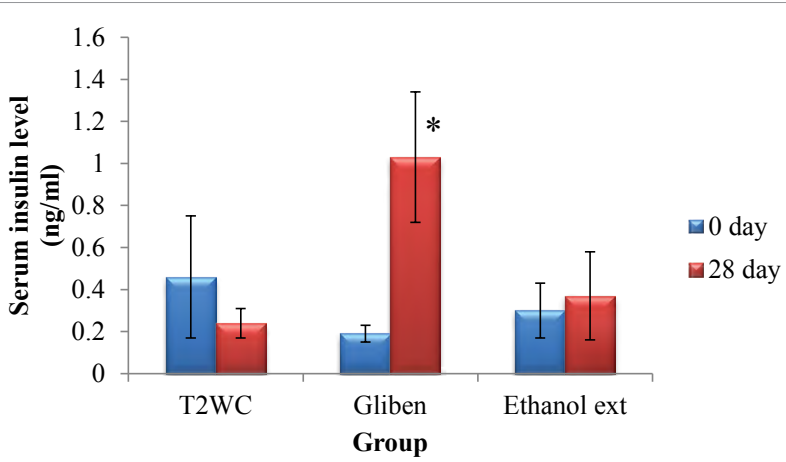

Figure 2: Effect of $P$. thyrsiflorus flower extract on the serum insulin level of STZ- induced Type 2 diabetic model rats. " $p<0.001$ compared water control group (ANOVA with post Hoc Bonferroni test).

\begin{tabular}{|c|c|c|c|c|c|}
\hline \multirow{2}{*}{ Group } & \multicolumn{5}{|c|}{ Body weight (g) } \\
\hline & 0 day & 7 day & 14 day & 21 day & 28 day \\
\hline $\begin{array}{c}\text { T2WC } \\
(n=6)\end{array}$ & $\begin{array}{c}192 \pm 21 \\
(100 \%)\end{array}$ & $\begin{array}{c}185 \pm 28 \\
(96 \%)\end{array}$ & $\begin{array}{c}188 \pm 32 \\
(98 \%)\end{array}$ & $\begin{array}{c}182 \pm 29 \\
(95 \%)\end{array}$ & $\begin{array}{c}193 \pm 34 \\
(101 \%)\end{array}$ \\
\hline $\begin{array}{l}\text { Gliben } \\
(n=6)\end{array}$ & $\begin{array}{c}182 \pm 13 \\
(100 \%)\end{array}$ & $\begin{array}{c}189 \pm 25 \\
(104 \%)\end{array}$ & $\begin{array}{l}183 \pm 8 \\
(101 \%)\end{array}$ & $\begin{array}{l}182 \pm 7 \\
(101 \%)\end{array}$ & $\begin{array}{c}182 \pm 16 \\
(100 \%)\end{array}$ \\
\hline $\begin{array}{l}\text { Ethanol ext } \\
\qquad(n=6)\end{array}$ & $\begin{array}{l}202 \pm 7 \\
(100 \%)\end{array}$ & $\begin{array}{c}193 \pm 19 \\
(96 \%)\end{array}$ & $\begin{array}{c}200 \pm 18 \\
(99 \%)\end{array}$ & $\begin{array}{c}195 \pm 20 \\
(97 \%)\end{array}$ & $\begin{array}{c}198 \pm 18 \\
(98 \%)\end{array}$ \\
\hline
\end{tabular}

Results are expressed as Mean \pm SD. ANOVA with post Hoc Bonferroni test was done.

Table 4: Effect of $P$. thyrsiflorus flowers extract on the body weight of Type 2 diabetic model rats.

\begin{tabular}{|c|c|c|c|c|}
\hline \multirow{2}{*}{ Group } & \multicolumn{2}{|c|}{ Cholesterol (mg/dL) } & \multicolumn{2}{|c|}{ TG (mg/dL) } \\
\cline { 2 - 5 } & $\mathbf{0}$ day & $\mathbf{2 8}$ day & 0 day & $\mathbf{2 8}$ day \\
\hline $\begin{array}{c}\text { T2WC } \\
(n=6)\end{array}$ & $\begin{array}{c}79 \pm 5.93 \\
(100 \%)\end{array}$ & $\begin{array}{c}73 \pm 8.28 \\
(92 \%)\end{array}$ & $\begin{array}{c}70 \pm 4.12 \\
(100 \%)\end{array}$ & $\begin{array}{c}59 \pm 8.56 \\
(84 \%)\end{array}$ \\
\hline $\begin{array}{c}\text { Gliben } \\
(n=6)\end{array}$ & $\begin{array}{c}81 \pm 8.87 \\
(100 \%)\end{array}$ & $\begin{array}{c}65 \pm 5.78 \\
(80 \%)\end{array}$ & $\begin{array}{c}77 \pm 7.53 \\
(100 \%)\end{array}$ & $\begin{array}{c}59 \pm 11.85 \\
(77 \%)\end{array}$ \\
\hline $\begin{array}{c}\text { Ethanol ext } \\
(n=6)\end{array}$ & $\begin{array}{c}80 \pm 11.21 \\
(100 \%)\end{array}$ & $\begin{array}{c}71 \pm 8.96 \\
(89 \%)\end{array}$ & $\begin{array}{c}70 \pm 9.09 \\
(100 \%)\end{array}$ & $\begin{array}{c}54 \pm 7.52 \\
(77 \%)\end{array}$ \\
\hline
\end{tabular}

Results are expressed as Mean \pm SD. Statistical analysis was done using ANOVA with post Hoc Bonferroni test.

Table 5: Effects of $P$. thyrsiflorus flowers extract on serum cholesterol and triglyceride levels of STZ-induced Type 2 diabetic model rats.

\begin{tabular}{|c|c|c|c|c|}
\hline \multirow{2}{*}{ Group } & \multicolumn{2}{|c|}{ HDL (mg/dL) } & \multicolumn{2}{c|}{ LDL (mg/dL) } \\
\cline { 2 - 5 } & $\mathbf{0}$ day & $\mathbf{2 8}$ day & 0 day & $\mathbf{2 8}$ day \\
\hline T2WC & $40 \pm 2.81$ & $33 \pm 3.25$ & $25 \pm 6.98$ & $28 \pm 10.62$ \\
$(n=6)$ & $(100 \%)$ & $(83 \%)$ & $(100 \%)$ & $(112 \%)$ \\
\hline Gliben & $40 \pm 3.08$ & $36 \pm 6.26$ & $26 \pm 7.07$ & $17 \pm 9.70$ \\
$(n=6)$ & $(100 \%)$ & $(90 \%)$ & $(100 \%)$ & $(65 \%)$ \\
\hline $\begin{array}{c}\text { Ethanol extract } \\
(n=6)\end{array}$ & $41 \pm 3.20$ & $41 \pm 3.39^{*}$ & $25 \pm 13.60$ & $19 \pm 9.05$ \\
& $(100 \%)$ & $(100 \%)$ & $(100 \%)$ & $(76 \%)$ \\
\hline
\end{tabular}

Results are expressed as Mean \pm SD. " $p<0.05$ vs Type 2 water control (ANOVA with post Hoc Bonferroni test).

Table 6: Effect of $P$. thyrsiflorus flowers extract on the serum HDL-C and LDL-C levels of STZ-induced Type 2 diabetic model rats.

is presented in Table 5. Ethanol extract of $P$. thyrsiflorus flowers caused non-significant reduction in total cholesterol level on $28^{\text {th }}$ day [Serum cholesterol $(\mathrm{M} \pm \mathrm{SD}) \mathrm{mg} / \mathrm{dl}, 0$ day $(80 \pm 11.21)$ vs. 28 day $(71 \pm 8.96)]$ $(\mathrm{p}<\mathrm{NS})$, Glibenclamide decreased serum cholesterol level by $20 \%$ when compared to the base line level. Type 2 control also showed $8 \%$ decrease of serum cholesterol level. In case of serum triglyceride (TG) level, there was a reduction of $23 \%$ in glibenclamide treated groups after 28 days study period. Ethanol extract treated group also showed a reduction in serum TG level by $16 \%$ (Table 5), although the reduction level was not significant.

Chronic effects of $P$. thyrsiflorus flowers extract on serum HDL-C and LDL-C levels of STZ-induced Type 2 diabetic model rats: The effects of chronic treatment with extract of $P$. thyrsiflorus flowers on the serum HDL- and LDL-cholesterol levels of type 2 diabetic model rats are summarized in Table 6 . It was found that at the end of the 28 days study period, HDL level increased significantly $(\mathrm{p}=0.031)$ in ethanol extract of $P$. thyrsiflorus treated group compared to water control group. Glibenclamide treated group was unable to increase serum HDL level at the end of 28 days study period when compared to the water control group. As it is seen from the table water control group had a $17 \%$ decrease in HDL level compared to its baseline value. In case of atherogenic LDL-cholesterol, the level was decreased by $24 \%$ with the treatment of ethanol extract of $P$. thyrsiflorus flowers $(25 \mathrm{mg} / \mathrm{dL}$ on the 0 day to $19 \mathrm{mg} / \mathrm{dL}$ on the $28^{\text {th }}$ day) at the end of the study period. Glibenclamide also decreased LDL level by $35 \%$ compared to the initial value. However, the decrease was not statistically significant for both the cases. On the other hand, control group showed a 12\% increase in serum LDL which is harmful for health. Type 2 diabetes is associated with marked imbalance in lipid metabolism [18]. As we know, the most vulnerable problem in dyslipidemia is the increase in atherogenic lipids i.e., increase in serum LDL-C, Triglyceride and total cholesterol levels with the reduction in good cholesterol (HDL-C) level [19-21]. It is now well established that elevated triglycerides and low high-density lipoprotein cholesterol (HDL-C) levels contribute to cardiovascular disease risk. This abnormal high level of serum lipids is mainly due to the uninhibited actions of lipophytic hormones on the fat depots mainly due to the action of insulin. The role of hypolipidemic agents is to correct dyslipidemia. In this study, at the end of the experimental period, ethanol extract of $P$. thyrsiflorus flowers decreased Total cholesterol, triglycerides and LDL-C level although non-significantly and significantly improved HDL-C level $(p=0.031)$ compared to water control group of Type 2 rats. This implies that ethanol extract of $P$. thyrsiflorus flowers can prevent or be helpful in reducing the atherogenic lipids in diabetes.

\section{Conclusion}

From the obtained results it may be concluded that, flowers of $P$. thyrsiflorus possesses hypoglycemic and to some extent hypolipidemic properties. The flowers of the plant contained 5 compounds which have been isolated and characterized. The obtained antidiabetic activity by the ethanolic extract of $P$. thyrsiflorus flowers may be due to the presence of these compounds, the activities of which remain to be explored in future.

\section{Acknowledgements}

The International Science Program (ISP) in Sweden, particularly the International Program in the Chemical Sciences (IPICS) and Ministry of Science and Technology, Government of the People's Republic of Bangladesh are gratefully acknowledged for financial support in conducting this study. The authors are also grateful to Prof Dr BP Sharma, Assam, India for kindly providing the $P$. thyrsiflorus flowers.

\section{References}

1. Patel DK, Prasad SK, Kumar R, Hemalatha S (2012) An overview on antidiabetic medicinal plants having insulin mimetic property. Asian Pac J Trop Biomed 2: 320-330.

2. Rizvi SI, Mishra N (2013) Traditional Indian Medicines Used for the Management of Diabetes Mellitus. Journal of Diabetes Research. 
Citation: Ahmed R, Sultana T, Routary R, Khan SH, Shaari K, et al. (2016) Chemistry and Antidiabetic Effects of Phlogocanthus thyrsiflorus Nees Flowers. Nat Prod Chem Res 4: 229. doi:10.4172/2329-6836.1000229

3. Mosihuzzaman M (2012) Herbal medicine in healthcare--an overview. Nat Prod Commun 7: 807-812

4. Mosihuzzaman M, Sydnes LK (2010) Herbal products in healthcare-challenges and potential. Comprehensive Bioactive Natural Products, Vols. I to VIII, Chapter 12, ISBN: 1933699507.

5. Mosihuzzaman M, Choudhary MI (2008) Protocols on Safety, Efficacy, Standardization, and Documentation of Herbal Medicine. Pure Appl Chem 80: 2195-2230.

6. Khare CP (2007) Indian Medicinal Plants: An Illustrated Dictionary, USA Springer Science Business Media, p: 478.

7. Kar A, Bortakur SK (2008) Wild vegetables of karbi-Anglong district, Assam. Natural Product Radiance 7: 448-460.

8. Tamang JP, Thapa MP, Sharma RM, Rai AK, Rai P, et al. (2005) Carrying capacity study of Teesta Basin in Sikkim. Biological Environment Food Resource, p: 8.

9. Gogoi B, Kakoti BB, Bora NS, Goswami AK (2013) Phytochemistry and Pharmacology of Phlogacanthus Thyrsiflorus Nees: A Review. Int J Pharm Sci Rev Res 23: 175-179.

10. Chakravarty S, Kalita JC (2012) Antiheperglycemic effect of flower of Phlogacanthus thyrsiflorus Nees on streptozotocin induced diabetic mice. Asian Pacific Journal of Tropical Biomedicine 2: S1357-S1361.

11. Agrawal PK, Jain DC, Gupta RK, Thakur RS (1985) Carbon - 13 NMR spectroscopy of steroidal saponins. Phytochemistry Reg 24: 2476-2496.

12. Kamboj A, Saluja AK (2011) Isolation of Stigmasterol and B-sitosterol From Petroleum Ether Extract of Aerial Parts of Ageratum Conyzoides (Asteraceae). International Journal of Pharmacy and Pharmaceutical Sciences 3: 94-96.
13. Chaturvedula VSP, Prakash I (2012) Isolation of Stigmasterol and ß-Sitostero from the dichloromethane extract of Rubus suavissimus. International Current Pharmaceutical Journal 1: 239-242.

14. Singh SA, Singh NR (2010) Antimicrobial Activity of Cassia didymobotrya and Phlogacanthus thyrsiflorus. J Chem Pharm Res 2: 304-308.

15. Barua AK, Chowdhury MK, Biswas S, Gupta CD, Banerjee SK, et al. (1985) The structure and stereochemistry of phlogantholide-A, a diterpene from Phlogacanthus thyrsiflorus. Phytochemistry 24: 2037-2039.

16. Peters NK, Frost JW, Long SR (1986) A plant flavone, luteolin, induces expression of Rhizobium meliloti nodulation genes. Science 233: 977-980.

17. Ode OJ, Asuzu IU (2014) Luteolin isolate from the methanol extract identified as the singlecarbon compound responsible for broad antiulcer activities of Cassia singueana Leaves. IOSR Journal of Pharmacy 4: 17-23.

18. Gadi R, Samaha FF (2007) Dyslipidemia in type 2 diabetes mellitus. Curr Diab Rep 7: 228-234.

19. Forrester JS, Makkar R, Shah PK (2005) Increasing high-density lipoprotein cholesterol in dyslipidemia by cholesteryl ester transfer protein inhibition: an update for clinicians. Circulation 111: 1847-1854.

20. Milionis HJ, Kakafika AI, Tsouli SG, Athyros VG, Bairaktari ET, et al. (2004) Effects of statin treatment on uric acid homeostasis in patients with primary hyperlipidemia. Am Heart J 148: 635-640.

21. Hyeung SL, Sung JW, Sae KK (2008) Hypolipidemic and Hepatoprotective effects of Picorrhiza Rhizome in high fat diet supplied mice. A prevention study. Biomolecules \& therapeutics 16: 46-53. 